\title{
SOCIAL FACTORS AS DETERMINANTS OF INVESTMENT IN MICRO INSURANCE: A STUDY WITH REFERENCE TO KOLLAM DISTRICT, KERALA
}

\author{
Ram Neelamegam \\ Department of Management Studies, Virudhunagar Hindu Nadars' Senthikumara Nadar College, India
}

\begin{abstract}
The potential of micro insurance is very high for a developing country like India where a major portion lives below poverty line. Micro insurance in India is a new concept and in the real sense, is yet to be tested for its suitability to the needs of target segment. Spreading awareness among this segment of insurable population and capacity building of the delivery organizations are major challenges. In several cases, social factors or guiding agencies like insurance agents, employers, and friends and relatives influence the prospective buyers to invest in the micro insurance policy. The present paper brings to light in micro insurance policy in Kollam district, Kerala.
\end{abstract}

Keywords:

Micro Insurance, Guiding Agencies/Social Factors, Service Quality Attributes

\section{INTRODUCTION}

Insurance is the best form of cover against risk that has been devised by man. Since its origin, insurance has become inevitable to every facet of human life from life coverage to building properties, from coverage of crop yield to health hazards. Now the insurance industry has embarked on a pro poor insurance programme, namely, micro insurance. Micro insurance provides insurance to low income people. A salient feature is, it is different from insurance in general as it is a low value product involving modest premium and benefit package which needs different marketing plan.

There are several benefits of micro insurance such as provision of financial cover, mobilization of saving and proper investment. In practice, there are different types of micro insurance like life insurance, health insurance, property insurance, crop insurance, disability insurance, disaster insurance, unemployment insurance and reinsurance. Micro insurance business may be done through the intermediaries of nongovernment organizations, self-help groups and micro finance institutions. There are different methods and models for micro insurance depending on the organization, institution and marketer involved. Each of the models has its own merits and limitations.

\section{LITERATURE REVIEW}

Ahuja Lka [1] reports that the decision to buy an insurance product in mainly affected by the advice of the family members, neighbors, agents, and also a desire to reduce income tax.

Allianz [2] opines that research influences on promotion of micro insurance in India, through marketing and branding of micro insurance in rural and semi urban areas. Consumers' protection receives attention through micro insurance.
Balasubramanian and Gupta [3] explained the challenges faced by the insurance industry in the contest of globalization.

B. Hermanto et al. [4] finds that a large section of the informal workers are potential candidates to take up micro insurance products as a substitute for, and/or complement to social security.

C. Basavanthappa and R. Laxman [5] report that the private insurance companies have made their presence felt. A healthy competition in the sector would be beneficial to both the players and the public.

Ganesan and Jayaprakash [6] opines India is a large nation with villages as its strength. So, getting rural through micro insurance is nothing but consolidation of the roots of insurance business.

B. Sahu [7] reports that MFI as distribution channel of micro insurance is found to be effective in reducing administrative cost. Micro credit related insurance commerce is one of the key driven for micro insurance business.

The study of Job Harms [8] reveals that there is a strong preference among potential micro insurance clients in rural Kenya for micro insurance policies as similar to insurance preference in developed countries.

R. Reddy et al. [9] states that micro insurance is quite different from other low income insurance products available in the market. It is time for all insurance companies to remodel the micro insurance products into the market and target as much as poor people for covering under micro insurance with financial services under micro insurance.

\section{RESEARCH PROBLEM}

The poor face more risks than the well off, but more importantly they are more vulnerable to the same risk. The prevalent forms of risk management which were appropriate earlier are no longer adequate. Micro insurance in conjunction with micro finance could go a long way in keeping this segment away from the poverty trap and would truly be an integral component of financial inclusion amid this backdrop, the present study sheds light on the social factors (guiding agencies) that influenced the policyholders to invest in micro insurance policy in Kollam district, Kerala.

\section{OBJECTIVE OF THE STUDY}

- To study the social factors influencing the investment in micro insurance policy.

- To examine the relationship between service quality variables of policy and social factors (that influenced to buy policy). 


\section{HYPOTHESIS}

H0: There is no significant association between demographic variables of respondents and social factors

H0: The mean scores for provision for loan (a service quality variable) are the same for different level of social factors that guided for buying policy.

Note:

- In the same way, 8 null hypotheses were formulated for the remaining eight service quality variables of insurance policy.

- There was also the performance of MANOVA to verify the following Null Hypothesis

$\mathrm{H} 0$ : There is no difference in the mean score of nine dependent variables (i.e., provision for loan and the like) for the six social factors that influenced to buy policy.

\section{DATA AND METHODOLOGY}

The study employed a descriptive cross sectional design using survey method where a structured questionnaire was administered to sample policyholders in different parts of Kollam district, Kerala. The reliability random sampling technique was used for the selection of sample 400 in number. Kukeran formula was used for determining the size of sample. The sample survey was conducted for seven month in the year 2016. Relevant statistical tools such as percentage calculation, mean, Cramer's V, ANOVA (one way) and Manova were used for the analysis of survey data.

Variable of the study: Respondents' demographic profile such as age, income, education, and annual income; factor's that guided the respondents to buy policy like agents, development officers, employers, friends and relatives; and service quality variables of the policy like provision of loan, less penal provision and affordable premium amount.

Guiding Agencies: The study reveals the important agencies guided the respondents to invest in micro insurance policy.

\section{RESULT AND DISCUSSION:}

Data for the study were collected from 400 policyholders in Kollam district. Frequency distribution of Social Economic Characteristic of respondents in exhibited in Table1.

Table.1. Demographic profile of Respondents

\begin{tabular}{|c|c|c|c|}
\hline \multicolumn{2}{|c|}{ Characteristic } & F & \% \\
\hline \multirow{3}{*}{ Area of Residence } & Urban & 61 & 15.25 \\
\cline { 2 - 4 } & Semi Urban & 61 & 15.25 \\
\cline { 2 - 4 } & Rural & 278 & 69.50 \\
\hline \multirow{4}{*}{ Age (years) } & $25-35$ & 63 & 15.75 \\
\cline { 2 - 4 } & $36-45$ & 128 & 32.00 \\
\cline { 2 - 4 } & $46-55$ & 146 & 36.50 \\
\cline { 2 - 4 } & 56 and above & 63 & 15.75 \\
\hline
\end{tabular}

\begin{tabular}{|c|c|c|c|}
\hline \multirow{4}{*}{ Gender } & Male & 151 & 37.75 \\
\cline { 2 - 4 } & Female & 249 & 62.25 \\
\hline \multirow{4}{*}{ Education level } & Primary Level & 92 & 23.00 \\
\cline { 2 - 4 } & Secondary Level & 167 & 41.75 \\
\cline { 2 - 4 } & Diploma & 29 & 7.25 \\
\cline { 2 - 4 } & Graduate & 112 & 28.00 \\
\hline \multirow{4}{*}{ Annual Income (Rs.) } & Below 50,000 & 42 & 10.50 \\
\cline { 2 - 4 } & $50,001-70,000$ & 85 & 21.30 \\
\cline { 2 - 4 } & $70,001-90,000$ & 101 & 25.30 \\
\cline { 2 - 4 } & 90,001 and above & 172 & 43.00 \\
\hline \multirow{2}{*}{ Marital Status } & Married & 344 & 86.00 \\
\cline { 2 - 4 } & Un Married & 56 & 14.00 \\
\hline
\end{tabular}

Source: Primary Data

Table.2. Social factors Influenced to Buy Insurance Policy

\begin{tabular}{|c|c|c|}
\hline Social Factors & $\mathbf{F}$ & $\mathbf{\%}$ \\
\hline Insurance Agents & 238 & 59.50 \\
\hline Development officer & 70 & 17.50 \\
\hline Employers & 15 & 3.75 \\
\hline Friends and Relatives & 28 & 7.00 \\
\hline Advertisement & 26 & 6.50 \\
\hline Others & 23 & 5.75 \\
\hline & 400 & 100.00 \\
\hline
\end{tabular}

Source: Primary data

\subsection{GUIDING AGENCIES}

The study reveals the social factors that influenced the policy holders to invest in micro insurance policy.

It is evident from the above table that the important agencies influenced the policyholders for taking the micro insurance are the insurance agents (59.50\%), followed by development officers $(17.50 \%)$.

\subsection{TEST OF SIGNIFICANCE BY CRAMER'S V}

In order to find out the strength of association between respondents' demographic variables and the above social factors that influenced them to buy the policy, the following null hypotheses' was tested by Cramer's V.

H0: There is no significant association between demographic variables and the social factors guided for buying micro policy. The application of Cromer's V (as a measure of index of agreement) indicates there is a strong association between the demographic variables such as respondents' area of residence, age, education, marital status and annual income and the social factors (that influence to buy micro insurance policy). However, there is no significant association between gender and social factors.

\subsection{SERVICE QUALITY ATTRIBUTES OF POLICY}

Before investing in a micro insurance policy a prospective buyer may look service quality attributes/variables of the policy 
such as affordable amount of premium, provision for loan, less penal provision speedy redress of grievances, cooperation of insurance officials, satisfactory service of agents, flexibility in premium payment, infrastructure of insurance company and agents' frequent visits.

During the study, an attempt was made to ascertain the effect of the foregoing guiding agencies / social factors (at six levels) on each of the above nine service quality attributes of micro insurance policy. In other words, the relationship between the service quality attributes (dependent variables) and social factors (independent variable) was statistically verified by ANOVA (one way) and MANOVA. ANOVA is an extension of t test. It is used to test the Homogeneity of several means. ANOVA denotes a set of techniques for studying the cause and effect of one or more factors or independent variables on a single dependent variable. When more than one dependent variable is studied, multivariate analysis of variance (MANOVA) is used. Here, ANOVA, was performed to test the following null hypotheses.

H0: The mean scores for provision for loan are the same for the different social factors that guided for buying insurance policy. Likewise, eight null hypotheses were formulated for the remaining eight other service quality attributes of policy.

Then was also the performance of MANOVA to test the following null hypothesis. To do MANOVA, there must be at least two dependent variables and one more independent variables/factors.

H0: There is no difference in mean score of nine dependent variables social factors (insurance agents and the like).

Table.3. Distribution of Respondents by Social factors that Influenced to buy policy

\begin{tabular}{|c|c|c|c|c|c|c|c|c|c|}
\hline \multicolumn{2}{|c|}{ Demographic Variables } & \multirow{2}{*}{\begin{tabular}{|c|} 
Insurance \\
agents
\end{tabular}} & \multirow{2}{*}{\begin{tabular}{|c|}
$\begin{array}{c}\text { Development } \\
\text { officers }\end{array}$ \\
32.79
\end{tabular}} & \multirow{2}{*}{$\begin{array}{c}\text { Employer } \\
3.28\end{array}$} & \multirow{2}{*}{\begin{tabular}{|l|} 
Adut. \\
8.20 \\
\end{tabular}} & \multirow{2}{*}{$\begin{array}{c}\text { Friends and } \\
\text { Relatives }\end{array}$} & \multirow{2}{*}{\begin{tabular}{|c|} 
Others \\
3.28 \\
\end{tabular}} & \multirow[t]{2}{*}{\begin{tabular}{|c} 
Cramer's \\
V
\end{tabular}} & \multirow[t]{2}{*}{ Sig. } \\
\hline \multirow{3}{*}{$\begin{array}{c}\text { Area of } \\
\text { Residence }\end{array}$} & Urban & & & & & & & & \\
\hline & Semi Urban & 44.26 & 22.95 & 6.56 & 13.11 & 6.56 & 6.56 & 0.184 & 0.003 \\
\hline & Rural & 65.11 & 12.95 & 3.24 & 4.68 & 7.91 & 6.12 & & \\
\hline \multirow{4}{*}{$\begin{array}{c}\text { Age } \\
\text { (years) }\end{array}$} & $25-35$ & 39.68 & 25.40 & 6.35 & 14.29 & 11.11 & 3.17 & & \\
\hline & $36-45$ & 60.16 & 17.97 & 7.03 & 3.13 & 5.47 & 6.25 & 0.177 & 0.001 \\
\hline & $46-55$ & 62.33 & 16.4 & 1.37 & 5.48 & 5.48 & 8.90 & & \\
\hline & 56 and above & 71.43 & 11.11 & 0.00 & 7.94 & 9.52 & 0.00 & & \\
\hline \multirow{2}{*}{ Gender } & Male & 64.90 & 3.91 & 3.97 & 7.95 & 6.62 & 2.65 & 0.141 & 0.162 \\
\hline & Female & 56.22 & 19.68 & 3.61 & 5.62 & 7.23 & 7.63 & & \\
\hline \multirow{4}{*}{$\begin{array}{c}\text { Education } \\
\text { level }\end{array}$} & Primary Level & 70.65 & 11.96 & 0.00 & 8.70 & 6.52 & 2.17 & & \\
\hline & Secondary Level & 61.08 & 19.16 & 0.00 & 4.79 & 5.99 & 8.98 & 0.231 & 0.000 \\
\hline & Diploma & 48.28 & 20.69 & 24.14 & 6.90 & 0.00 & 0.00 & & \\
\hline & Graduate & 50.89 & 18.75 & 7.14 & 7.14 & 10.71 & 5.36 & & \\
\hline \multirow{4}{*}{$\begin{array}{c}\text { Annual } \\
\text { Income } \\
\text { (Rs.) }\end{array}$} & Below 50,000 & 59.52 & 26.19 & 2.38 & 0.00 & 2.38 & 9.52 & & \\
\hline & $50,001-70,000$ & 45.88 & 36.47 & 2.35 & 3.53 & 2.35 & 9.41 & 0.221 & 0.000 \\
\hline & $70,001-90,000$ & 69.31 & 13.86 & 2.97 & 2.97 & 7.92 & 2.97 & & \\
\hline & 90,001 and above & 60.47 & 8.14 & 5.32 & 11.63 & 9.88 & 4.65 & & \\
\hline \multirow{2}{*}{$\begin{array}{c}\text { Marital } \\
\text { Status }\end{array}$} & Married & 63.95 & 13.08 & 4.36 & 6.10 & 6.98 & 5.52 & 0.312 & 0.000 \\
\hline & Un Married & 32.14 & 44.64 & 0.00 & 8.93 & 7.14 & 7.14 & & \\
\hline
\end{tabular}

Table.4. Relationship between social factors and service quality of policy

\begin{tabular}{|c|c|c|c|c|c|c|c|c|c|c|}
\hline \multirow{3}{*}{$\begin{array}{c}\text { Dependent } \\
\text { Variable }\end{array}$} & \multicolumn{6}{|c|}{ Social factors influenced to take policy } & \multirow{2}{*}{\multicolumn{2}{|c|}{ ANOVA }} & \multirow{2}{*}{\multicolumn{2}{|c|}{ MANOVA }} \\
\hline & \multirow{2}{*}{\begin{tabular}{|c|}
$\begin{array}{c}\text { Insurance } \\
\text { agents }\end{array}$ \\
Mean \\
\end{tabular}} & \multirow{2}{*}{\begin{tabular}{|c|}
$\begin{array}{c}\text { Developments } \\
\text { officers }\end{array}$ \\
Mean \\
\end{tabular}} & \multirow{2}{*}{\begin{tabular}{|c|} 
Employers \\
Mean
\end{tabular}} & \multirow{2}{*}{\begin{tabular}{|l|} 
Advt. \\
Mean
\end{tabular}} & \multirow{2}{*}{$\begin{array}{c}\text { Friends } \\
\text { and } \\
\text { relatives }\end{array}$} & \multirow{2}{*}{\begin{tabular}{|l|} 
Other \\
Mean \\
\end{tabular}} & & & & \\
\hline & & & & & & & $\mathbf{F}$ & Sig. & $\mathbf{F}$ & Sig. \\
\hline Provision for loan & 2.81 & 2.86 & 2.67 & 2.54 & 2.50 & 2.70 & 0.421 & 0.834 & & \\
\hline $\begin{array}{c}\text { Affordable } \\
\text { premium }\end{array}$ & 3.95 & 3.23 & 4.00 & 3.62 & 3.82 & 4.26 & 5.872 & 0.000 & & \\
\hline $\begin{array}{c}\text { Flexibility in } \\
\text { Premium Payment }\end{array}$ & 3.84 & 3.39 & 3.20 & 3.50 & 4.14 & 4.04 & 3.743 & 0.003 & & \\
\hline
\end{tabular}




\begin{tabular}{|c|c|c|c|c|c|c|c|c|c|c|}
\hline $\begin{array}{c}\text { Less panel } \\
\text { provision }\end{array}$ & 3.83 & 3.21 & 3.53 & 3.38 & 3.93 & 4.17 & 4.802 & 0.000 & \\
\hline $\begin{array}{c}\text { Agents } \\
\text { satisfactory }\end{array}$ & 3.78 & 3.06 & 2.87 & 3.50 & 4.21 & 4.09 & 9.151 & 0.000 & & \\
\hline $\begin{array}{c}\text { Service contact } \\
\text { agents }\end{array}$ & 3.04 & 2.99 & 1.93 & 3.35 & 2.93 & 2.26 & 3.482 & 0.004 & 3.841 & 0.000 \\
\hline $\begin{array}{c}\text { Company } \\
\text { infrastructure }\end{array}$ & 3.09 & 2.89 & 2.87 & 2.85 & 2.96 & 3.04 & 0.371 & 0.868 & & \\
\hline $\begin{array}{c}\text { Speedy redressal } \\
\text { of grievances }\end{array}$ & 2.82 & 3.10 & 3.20 & 4.04 & 2.93 & 3.09 & 4.090 & 0.001 & & \\
\hline $\begin{array}{c}\text { Cooperation of } \\
\text { officials }\end{array}$ & 3.16 & 2.57 & 3.33 & 4.04 & 3.18 & 2.87 & 4.634 & 0.000 & \\
\hline
\end{tabular}

Source: Primary data. Result Calculated

It is clear from the above table that the social factors guiding micro insurance policy significantly for the (dependent) variables of insurance such as affordable amount of premium, flexibility in payment of premium, less penal provision, satisfactory service of agents, agents contract with respondents, speedy redress of grievances, and cooperativeness of insurance officials as the $\mathrm{F}$ value is less than 0.05 . But for the other two variables, namely, provision for loan and infrastructure of the insurance company there is no effect (no significant variance) of the social factors guiding the respondents to invest in micro insurance policy.

\section{SUGGESTION AND CONCLUSION}

The investigation unveils the insurance agents (followed by the development officers) are the important guiding agencies in persuading the respondents to invest in micro insurance policy. The application of Cramer's V indicates that there is a strong association between the guiding agencies (including the micro insurance agents) and the socio economic characteristics of the policyholders (such as area of residence, age, education level, marital status and annual income). This strongly suggests for motivating the performance of the agents by raising the rate of incentives given to them, conducting periodical training and the like further, the performance of ANOVA and MANOVA reveals that there is variance in the service quality attributes of policyholders for the different levels of guiding agencies. This suggests for continued attention on service quality attributes such as affordable amount of premium, less penal amount, satisfactory service of agents, cooperation of insurance officials, timely redressal of clients' grievances and contact of insurance agents. Such a reasonable measure in the furtherance of the interest of the poor is in dire need.

\section{REFERENCES}

[1] Ahuja Alka, "Personal Insurance Decision Making process in India", Ph.D Dissertation, Department of Commerce, University of Delhi, 2010.

[2] Allianz, "Micro Insurance: Demand and Market ProspectsIndia",

Available

at: http://www.undp.org/content/dam/aplaws/publication/en/pu blications/capacity-development/microinsurance-demandand-market-prospects-for-india/Microinsurance.pdf

[3] T.S. Balasubramanian and S.P. Gupta, "Insurance Business Environment", Insurance Institute of India, 2000.

[4] Bambang Hermanto, Akbar Z Ali, Ratna Derina, Anna Amalyah Agus and Sigit S. Wibowo, "Social Security Policy Rejuvenation through Accelerated Growth in Micro Insurance Industry", Technical Report, Australia Indonesia Governance Research Partnership, pp. 1-22, 2009.

[5] C. Basavanthappa and R. Laxman, "Performance of Life Insurance Companies: A Comparative Study", Southern Economist, Vol. 42, pp. 1-6, 2009.

[6] S. Ganesan and S. Jayaprakash, "Micro Bancassurance Model in India", Proceedings of $11^{\text {th }}$ Annual Asia Pacific Risk and Insurance Association, pp. 1-10, 2008.

[7] Basant K. Sahu, "Micro Insurance for the Bottom of the Pyramid Market in India: Outreach and Efficacy. Banker of the way forward", Available at: http:/www.docstoc.com/docs/26246380/microinsurance for the bottom of the pyramid, Accessed on 2014.

[8] Job Harms, "Micro Insurance Product Design: Consumer Preference in Kenya", Available at: http://www.impactinsurance.org/sites/default/files/repaper4 .pdf,

[9] B. Ramachandra Reddy, M. Gurumohan Reddy and E. Lavanya, "Role of Micro Insurance in Agriculture", The Insurance Times Magazine, Vol. 31, 2011. 